Journal of Applied Pharmaceutical Science Vol. 2 (9), pp. 119-121, September, 2012

Available online at http://www.japsonline.com

DOI: $10.7324 /$ JAPS.2012.2923

ISSN 2231-3354 (cc) BY-NC-SA

\title{
Evaluation of Anticonvulsant Activity of Zinc in Albino Rats
}

\author{
Sharanabasayyaswamy B Hiremath and Mohammad Ameeruddin Kamdod \\ Department of Pharmacology, SDM College of Medical Sciences and Hospital, Dharwad, Karnataka, India.
}

\section{ARTICLE INFO}

Article history:

Received on: 03/09/2012

Revised on: 16/09/2012

Accepted on: 22/09/2012

Available online: 28/09/2012

Key words:

Zinc sulfate,

Maximum Electro-shock

method, Photo-actometer

\begin{abstract}
Mechanism of action of both magnesium and zinc in mediating their antidepressant activities is supposed to be through NMDA receptor antagonism. In the background of similarity in mechanism of action of zinc and magnesium as antidepressant through antagonism of NMDA receptors and evidences for anticonvulsant actions of magnesium being mediated through NMDA receptors blockade; present study was designed to test whether zinc has an additional anticonvulsant activity. Thirty six albino rats of either sex were divided in to 6 groups with 6 animals in each group. Group-I received distilled water $(1 \mathrm{ml} / \mathrm{kg}$ body weight) was control group. Group-II receiving phenytoin sodium $(20 \mathrm{mg} / \mathrm{kg}$ body weight) was the standard group. Group-III, IV and $\mathrm{V}$ were test groups receiving zinc sulfate at doses of $30 \mathrm{mg} / \mathrm{kg}, 150 \mathrm{mg} / \mathrm{kg}$ and $300 \mathrm{mg} / \mathrm{kg}$ respectively. Animals were screened for anticonvulsant activity by Maximum Electroshock (MES) method and for generalized CNS depressant effect by photo-actometer method. With regard to anticonvulsant activity there was no statistically significant differences between any of the zinc sulfate treated groups with control and standard drug phenytoin. There was no evidence for possible anticonvulsant activity of zinc after single dose treatment at three selected doses in presence of generalized CNS depressant effect.
\end{abstract}

\section{INTRODUCTION}

Zinc is one of the important ions attributed to multiple physiological functions in our body (Frassinetti et al., 2006). With regards to its role in CNS; zinc has been associated with disorders like epilepsy, alzheimer's disease and alleviation of N-Methyl-DAspartate (NMDA) mediated pain (Sensi et al., 2009 and Nozaki et al., 2011). Preliminary studies support that zinc may have antidepressant activity and hence its probable role in mood disorders also (Szewczyk et al., 2008). Apart from zinc another divalent ion magnesium has also been shown to have antidepressant activity (Szewczyk et al., 2008). Mechanism of action of both magnesium and zinc in mediating their antidepressant activities is supposed to be through NMDA receptor antagonism (Szewczyk et al., 2008). Magnesium has

\footnotetext{
* Corresponding Author Dr. Sharanabasayyaswamy B Hiremath, Department of Pharmacology, SDM College of Medical Sciences and Hospital, Dharwad, Karnataka, India, Ph : 09986160714
}

been found to be beneficial in treating certain medical emergencies and it is a preferred anticonvulsant in prophylaxis and treatment of preeclampsia and eclampsia (Frakes et al., 1997). Though mechanism behind its anticonvulsant action is not clear, evidences for it being mediated through antagonism of NMDA receptors are strongly supportive (Cotton et al., 1993 and Hallak et al.,1998). In the background of similarity in mechanism of action of zinc and magnesium as antidepressant through antagonism of NMDA receptors and evidences for anticonvulsant actions of magnesium being mediated through NMDA receptors blockade; present study was designed to test whether zinc has an additional anticonvulsant activity. Like magnesium, zinc could also find its application in treatment of medical emergency conditions and as an anticonvulsant in preeclampsia and eclampsia. Considering the confounding peripheral effect of magnesium on muscle tone/motor activity in mediating its anticonvulsant activity effect of zinc on muscle tone/motor activity was also screened for (Krauss et al., 1989). 
Salt of zinc (as zinc sulfate) at various doses were compared with phenytoin sodium as standard anticonvulsant drug for their anticonvulsant activity.

\section{MATERIALS AND METHODS}

Animals

Healthy male albino rats weighing 150-250g from central animal house of SDM medical college and Hospital Dharwad were screened for inclusion into the study. Thirty six animals reared under standard housing conditions of 12 hours light-dark cycle with free access to food and water were selected. Animals were divided into six groups with six animals in each group. Study was conducted in the department of pharmacology after the approval from Institute Animal Ethics Committee.

\section{Groups}

Group-I receiving distilled water at doses of $1 \mathrm{ml} / \mathrm{kg}$ body weight was control group. Group-II receiving phenytoin sodium at dose of $20 \mathrm{mg} / \mathrm{kg}$ body weight was the standard group. Group-III, IV and $\mathrm{V}$ were test groups receiving zinc sulfate at doses of $30 \mathrm{mg} / \mathrm{kg}, 150 \mathrm{mg} / \mathrm{kg}$ and $300 \mathrm{mg} / \mathrm{kg}$ respectively.

\section{Drugs}

Solutions of zinc sulfate were prepared by dissolving the zinc sulfate salt in distilled water. Distilled water, injection phenytoin sodium $(50 \mathrm{mg} / \mathrm{ml})$ were directly procured from the pharmacy. Zinc salt was purchased from NICE phermaceuticals Bangalore. All the drugs were administered by intraperitoneal (i.p) route 30 minutes before screening for anticonvulsant activity by maximum electroshock (MES) screening method and generalized CNS depressant effect by photo-actometer method. Dose of phenytoin sodium $(20 \mathrm{mg} / \mathrm{kg})$ was the standard dose used in screening of its anticonvulsant activity in rats (Standley et al., 1995). One of the dose of zinc sulfate $(30 \mathrm{mg} / \mathrm{kg}$ ) used here was the effective antidepressant dose in rats (Kroczka et al., 2001). As the effective anticonvulsant dose $(270 \mathrm{mg} / \mathrm{kg})$ of magnesium sulfate was higher than its antidepressant dose $(15-50 \mathrm{mg} / \mathrm{kg})$, we used $300 \mathrm{mg} / \mathrm{kg}$ body weight dose of zinc sulfate a dose 10 times its antidepressant dose $(30 \mathrm{mg} / \mathrm{kg})$ as an anticipated anticonvulsant dose and an intermediate dose of $150 \mathrm{mg} / \mathrm{kg}$ body weight as an additional test dose ( Poleszak et al., 2005).

\section{Anti-convulsant screening method}

Maximum Electroshock (MES) method was used to screen for the anticonvulsant activity. A stimulus of $150 \mathrm{~mA}$ fixed current and $60 \mathrm{~Hz}$ pulse frequency for $0.2 \mathrm{sec}$ was administered by electro-convulsometer through bilateral ear electrodes. Following parameters were recorded in all animals: Time for onset of seizure ('To') as indicated by Tonic Hindlimb Extension (THE), duration of tonic phase ('Tt'), duration of clonic phase ('Tc') and total duration of seizure ('Td'). Prior to the screening for anticonvulsant activity animals were screened for generalized CNS depressant effect by photo-actometer method after 30 minutes of administration of the test drugs.

\section{Screening for generalized CNS depressant effect}

Photo-actometer apparatus used to screen the generalized CNS depressant effects of drugs consisted of an activity cage of 30 x $30 \times 30 \mathrm{~cm}$ in dimension with a wire mesh floor. Six pairs of light transmitters and receivers placed around the outer periphery of the activity cage at a suitable height from the floor of the cage. The locomotor activity of the animal is recorded when it interrupts any one or more light beams. Each animal was placed in the compartment of the apparatus and number of counts recorded after 10 minutes were noted.

\section{Statistical analysis}

Mean and standard deviations values of all the parameters after treatment with test drug in each group were calculated. The difference and statistical significance between the groups with regard to all the parameters were analyzed by Analysis of variance (ANOVA) method followed by Bonferroni's post-hoc analysis.

\section{RESULTS AND DISCUSSSON}

With regard to anticonvulsant activity; in three of the four parameters i.e 'To' $(\mathrm{p}=0.000)$; 'Tt' $(\mathrm{p}=0.000)$ and 'Tc' $(\mathrm{p}=$ $0.002)$ except ' $\mathrm{Td}$ ' $(\mathrm{p}=0.605)$ results of two way ANOVA suggest statistically significant differences between the groups (Table.1). However post-hoc test results for multiple comparisons attributed the significance to the difference of control and all zinc sulphate groups with standard drug phenytoin sodium. No statistically significant increase in 'To'; 'Tt' and ' $\mathrm{Tc}$ ' were observed due to either of any dose of zinc sulfate on comparison with control group (Table.2).

Table. 1: Effect of different drugs on the parameters of Anticonvulsant screening method.

\begin{tabular}{lcccc}
\hline \multicolumn{1}{c}{ Groups } & $\begin{array}{c}\text { 'To' } \\
(\text { Mean } \pm \text { SD) }\end{array}$ & $\begin{array}{c}\text { 'Tt' } \\
(\text { Mean } \pm \text { SD) }\end{array}$ & $\begin{array}{c}\text { 'Tc' } \\
(\text { Mean } \pm \text { SD) }\end{array}$ & $\begin{array}{c}\text { 'Td' } \\
(\text { Mean } \pm \text { SD) }\end{array}$ \\
\hline Control & $2.3 \pm 0.73$ & $7.36 \pm 1.12$ & $8.72 \pm 1.71$ & $16.08 \pm 1.53$ \\
Phenytoin & $5.06 \pm 0.55$ & $2.41 \pm 0.39$ & $11.9 \pm 3.93$ & $14.31 \pm 3.94$ \\
Zinc & $1.95 \pm 0.45$ & $8.69 \pm 1.41$ & $4.72 \pm 1.49$ & $13.41 \pm 0.72$ \\
300mg/kg & & & & \\
Zinc & $2.99 \pm 1.06$ & $5.19 \pm 1.9$ & $8.73 \pm 2.85$ & $13.92 \pm 4.55$ \\
$\mathbf{1 5 0 m g / k g}$ & & & & \\
Zinc & $2.95 \pm 0.64$ & $6.59 \pm 1.85$ & $7.47 \pm 2.77$ & $14.06 \pm 2.66$ \\
30mg/kg & & & &
\end{tabular}

Mean values indicate time in seconds

'To': Time for onset of seizure; 'Tt': Duration of tonic phase 'Tc': Duration of clonic phase; 'Td': Total duration of seizure.

Results of photo-actometer were also significant by two way ANOVA $(\mathrm{p}=0.002)$. However unlike anticonvulsant activity when compared to control group mean counts (215 \pm 70.6$)$; statistically significant decrease in the mean counts were attributed to $30 \mathrm{mg} / \mathrm{Kg} \mathrm{ZnSo} 4(79.3 \pm 32.6)$ and $300 \mathrm{mg} / \mathrm{Kg} \mathrm{ZnSo} 4(87.7 \pm 38.1)$ groups apart from phenytoin $(91.7 \pm 43.7)$ group. 
Table. 2: Results of group wise comparison of anticonvulsant activity.

\begin{tabular}{|c|c|c|c|c|}
\hline Comparison & $\begin{array}{l}\text { 'To' (p- } \\
\text { value) }\end{array}$ & $\begin{array}{l}\text { 'Tt' (p- } \\
\text { value) }\end{array}$ & $\begin{array}{l}\text { 'Tc' (p- } \\
\text { value) }\end{array}$ & $\begin{array}{l}\text { 'Td' (p- } \\
\text { value) }\end{array}$ \\
\hline C vs P & $\mathrm{p}<0.05$ & $p<0.05$ & NS & NS \\
\hline C vs Z300 & NS & NS & NS & NS \\
\hline C vs $\mathrm{Z150}$ & NS & NS & NS & NS \\
\hline C vs Z30 & NS & NS & NS & NS \\
\hline P vs $\mathrm{Z300}$ & $\mathrm{p}<0.05$ & $\mathrm{p}<0.05$ & $\mathrm{p}<0.05$ & NS \\
\hline P vs Z150 & $\mathrm{p}<0.05$ & $\mathrm{p}<0.05$ & NS & NS \\
\hline P vs $\mathrm{Z30}$ & $\mathrm{p}<0.05$ & $p<0.05$ & NS & NS \\
\hline Z300 vs Z150 & NS & $\mathrm{p}<0.05$ & NS & NS \\
\hline Z300 vs Z30 & NS & NS & NS & NS \\
\hline Z150 vs Z30 & NS & NS & NS & NS \\
\hline
\end{tabular}

Interestingly though $30 \mathrm{mg} / \mathrm{kg} \mathrm{ZnSo} 4$ group showed significant decrease in the counts, this was not evident with $150 \mathrm{mg} / \mathrm{kg} \mathrm{ZnSo} 4$ group (117 \pm 79.3$)$.

Results of the study rule out possible anticonvulsant activity of $\mathrm{ZnSo} 4$ after single dose treatment at three selected doses. Interestingly none of the groups including phenytoin treated standard group showed significant effect on total duration of seizure. Trend toward shortened duration of clonic phase in $300 \mathrm{mg} / \mathrm{kg} \mathrm{ZnSo} 4$ treated group was evident. Though there was no statistically significant difference between control group and this group, a statistically significant difference with regard to total duration of seizure between phenytoin and $300 \mathrm{mg} / \mathrm{kg} \mathrm{ZnSo} 4$ group would indicate supportive role of zinc to major anticonvulsants rather than as a monotherapy. Long term orally administered zinc may provide facilitator benefit and help in decreasing dose or increasing efficacy of major anticonvulsant drugs. Evidence on facilitator action of zinc on the antidepressant activity of one of the established antidepressant drug is an indirect evidence to our hypothesis (Szewczyk et al., 2008). Further studies employing combination of low doses of established anticonvulsants and long term orally administered zinc could enlighten on the possible facilitator action of zinc.

Statistically significant decrease in photo-actometer counts in phenytoin and $300 \mathrm{mg} / \mathrm{kg} \mathrm{ZnSo} 4$ group was anticipated. It could suggest possible generalized depressant effects of zinc on the CNS. Interestingly there was lack of generalized CNS depressant effect of zinc at dose of $150 \mathrm{mg} / \mathrm{kg}$ though $30 \mathrm{mg} / \mathrm{kg}$ ZnSo4 group showed significant decrease in photo-actometer counts. This might indicate possible dose dependent effect of zinc on the CNS.

\section{ACKNOWLEDGMENT}

We are very much thankful to Dr. Niranjan Kumar, Medical Director, SDM College of Medical Sciences, Dharwad and Dr. Prasanna Bhandari, Associate professor, Department of Pharmacology, SDM College of Medical Sciences, Dharwad for their help and support.

\section{REFERENCES}

Cotton DB, Hallak M, Janusz C, Irtenkauf SM, Berman RF. Central anticonvulsant effects of magnesium sulfate on N-methyl-Daspartate-induced seizures. Am J Obstet Gynecol. 1993;168:974-8.

Frakes MA, Richardson LE. Magnesium sulfate therapy in certain emergency conditions. American journal of emergency medicine. $1997 ; 15 ; 182-7$.

Frassinetti S, Bronzetti GL, Caltavuturo L, Cini M, Croce CD. The Role of Zinc in Life: A Review. Journal of Environmental pathology, Toxicology and Oncology. 2006; 25: 597-610.

Hallak M. Effect of parenteral magnesium sulfate administration on excitatory amino acid receptors in the rat brain. Magnes Res. 1998;11:117-31.

Krauss GL, Kaplan P, Fisher RS. Parenteral magnesium sulfate fails to control electroshock and pentylenetetrazol seizures in mice. Epilepsy Res. 1989;4:201-6.

Kroczka B, Brañski P, $\mathrm{Pa}^{3}$ ucha A, Pilc A, Nowak G. Antidepressant-like properties of zinc in rodent forced swim test. Brain Res Bull. 2001, 55, 297-300.

Nozaki C, Vergnano AM, Filliol D, Ouagazzal AM, Le Goff A, Carvalho S, et al. Zinc alleviates pain through high-affinity binding to the NMDA receptor NR2A subunit. Nature neuroscience. 2011;14:1017-25.

Poleszak E, Piotr WŸ, Kêdzierska E, Radziwon-Zaleska M, Pilc A, Fidecka S, Nowak G. Effects of acute and chronic treatment with magnesium in the forced swim test in rats. Pharmacological Reports. 2005; 57:654-8.

Sensi SL, Paoletti P, Bush AI, Sekler I. Zinc in the physiology and pathology of the CNS. Nature reviews neuroscience. 2009; 10:780-92.

Standley CA, Irtenkauf SM, Cotton DB. Anticonvulsant Effects of Magnesium Sulfate in HippocampaI-Kindled Rats. J Biomed Sci. 1995;2:57-62.

Szewczyk. B, Poleszak E, Sowa-Kuæma M, Siwek M, Dudek, $\mathrm{D}$, Pokraoeniewicz BR, et al. Antidepressant activity of zinc and magnesium in view of the current hypotheses of antidepressant action. Pharmacological Reports. 2008:60:588-99.

\section{How to cite this article:}

Sharanabasayyaswamy B Hiremath, Naveen Kumar Madalageri. Evaluation of Anticonvulsant Activity of Zinc in Albino Rats. J App Pharm Sci. 2012; 2(9): 119-121. 